\title{
Pembuatan Aplikasi Portal Akademik Berbasis Mobile (Studi Kasus: D3 Manajemen Informatika FMIPA Universitas Riau)
}

\author{
Sukamto $^{1}$, Roni Salambue ${ }^{2}$, Elfizar ${ }^{3}$, Anna Kaswari ${ }^{4}$ \\ 1,2,3,4 Jurusan Ilmu Komputer, Fakultas Komputer, FMIPA Universitas Riau, Pekanbaru \\ 1,2,3,4 Kampus Bina Widya, Km 12,5 Simpang Baru, Pekanbaru, 28293 \\ e-mail: ${ }^{1}$ sukamtonursyam@gmail.com, ${ }^{2}$ roni.salambue@ gmail.com, ${ }^{3}$ elfizarmd@ gmail.com, \\ 4anna_kaswari@mail.com
}

\begin{abstract}
Abstrak
Penelitian ini membahas tentang aplikasi portal akademik berbasis mobile, studi kasus pada D3 Manajemen Informatika Fakultas Matematika dan Ilmu Pengetahuan Alam Universitas Riau. Aplikasi ini dapat mempermudah mahasiswa khususnya mahasiswa D3 Manajemen Informatika dalam melakukan pengisian Kartu Rencana Studi dengan menggunakan Smartphone Android. Pembuatan Aplikasi mobile ini menggunakan bahasa pemograman Java dan MySQL sebagai database. Sedangkan dalam perancangan aplikasi menggunakan Unified Modeling Language (UML) yaitu Use Case Diagram, Class Diagram, Activity Diagram, dan Sequence Diagram.
\end{abstract}

Kata kunci: Aplikasi Portal Akademik, Mobile, Kartu Rencana Studi, Smartphone Android.

\begin{abstract}
This research discusses about Portal Academic Application based Android Mobile with case at Diploma of Information Management the Faculty of Mathematics and Natural Sciences, University of Riau. This application can facilitate in particular the Student Information Management Diploma in charging Card Study Plan that has been using smartphones based on Android. Making mobile applications using the programming language Java, and PHP, and then MySQL as database. While the design of the application using the Unified Modeling Language (UML), Use Case Diagrams, Class Diagrams, Activity Diagrams, and Sequence.
\end{abstract}

Keywords: Portal Academic Application, Android Mobile, Study Plan Card, Android Smatrphone.

\section{Pendahuluan}

Seiring dengan perkembangan teknologi informasi yang sedemikian pesat, pengaksesan terhadap data atau informasi yang tersedia dapat berlangsung dengan cepat, efisien serta akurat. Metoda-metoda baru dalam bidang komunikasi via selular juga dihasilkan, baik terhadap transmisi data maupun isi dari data, terus dikembangkan untuk bisa menyesuaikan diri dari pesatnya perkembangan teknologi informasi.

Pengisian Kartu Rencana Studi (KRS) merupakan bagian yang berperan penting dalam sistem Akademik di Universitas Riau (UR). Mahasiswa harus mengisi KRS untuk menentukan kelas perkuliahan dan mata kuliah yang akan diambil pada semester berikutnya. Hal ini menjadikan pengisian KRS sebagai hal yang vital bagi kelancaran perkuliahan mahasiswa karena jika mahasiswa tidak mengisi KRS maka mahasiswa bersangkutan dinyatakan cuti kuliah. Kebanyakan mahasiswa pada saat pengisian KRS, mereka melakukannya di Warung Internet (Warnet) atau di tempat-tempat yang terdapat jaringan Hotspot. 
Mahasiswa UR mengakses portal Akademik melalui Web Browser untuk melakukan pengisian KRS, tahapan-tahapan yang dilalui ketika mengakases portal akademik melalui Web Browser akan memerlukan waktu yang cukup lama. Jika beberapa tahun lalu sistem informasi akademik terbatas dalam bentuk website, kini sistem informasi akademik juga sudah mulai dikembangkan pada perangkat mobile berbasis android. Hal ini cukup beralasan mengingat terdapat segudang kelebihan yang dimiliki oleh aplikasi berbasis android. Dengan menggunakan sistem informasi akademik berbasis android, pengguna aplikasi dapat menggali informasi dimana saja dan kapan saja seperti: Jadwal Kuliah Mandiri, Pembayaran SPP Online (tidak perlu antri) mengisi KRS (Kartu Rencana Studi), melihat KHS (Kartu Hasil Studi), Perwalian, Diskusi, pengumuman nilai dan masih banyak lagi, semua itu bisa dilakukan lewat smartphone

Keunggulan utama dalam mengembangkan Mobile adalah dalam hal mobilitas. Aplikasi pada smartphone android dapat digunakan dimana saja dan kapan saja. Berkat karakteristik tersebut, Aplikasi Mobile menjadi jawaban yang tepat untuk mengatasi kendala pada sistem informasi akademik berbasis web ataupun desktop. Dengan aplikasi sistem informasi akademik berbasis mobile, pengguna sistem informasi dapat mengakses informasi langsung dari smartphone android mereka. Disamping dari sisi mobilitas, pengembangan sistem informasi akademik berbasis mobile juga menjadi kian optimal berkat adanya fitur-fitur khas smartphone seperti fitur notifikasi. Dengan fitur notifikasi maka informasi akan lebih cepat tersalurkan ke pengguna aplikasi. Tentu penggunaan aplikasi sistem informasi akademik berbasis mobile lebih efektif jika dibandingkan dengan menggunakan sistem informasi akademik web based yang harus menunggu pengguna untuk mengakses web.

Aplikasi Mobile merupakan salah satu aplikasi yang dapat diakses melalui perangkat Mobile atau Personal Digital Assistant (PDA). Aplikasi ini dapat digunakan dengan mudah walaupun pengguna berpindah dari satu tempat ketempat lain tanpa terjadi pemutusan atau terputusnya komunikasi.

Beberapa penelitian tentang Sistem Informasi Akademik, antara lain Aplikasi KRS Online Berbasis Web dan Mobile [1], yang menyimpulkan bahwa aplikasi pengisian KRS online berbasis web dan mobile di Program Studi DIII Teknik Komputer PoliTeknik Harapan Bersama maka proses pengisian KRS akan lebih praktis dan efisien baik dari segi waktu maupun biaya. Sistem Informasi Akademik Berbasis Web pada SMK [2], memberikan solusi yang lebih cepat dalam pengolahan nilai, pembuatan laporan lebih efektif dan efisen karena penyimpanan data sudah dalam database. Adopsi Sistem Informasi Akademik Perguruan Tinggi [3], yang menghasilkan penggunaan sistem informasi akademik yang mendukung adanya suatu pengaruh yang positif dan signifikan terhadap perceived usefulness (U) dan behavioral intention (BI). Portal Akademik Semi-Realtime AMIK dan STIKOM [4], hasilnya adalah bahwa aplikasi ini dibuat sebagai sarana informasi dalam menyajikan informasi akademik yang bersifat online bagi kalangan mahasiswa.

Selanjutnya, Perancangan Master Plan Sistem Informasi Akademik STT Dharma Iswara Madiun [5], hasilnya adalah berupa panduan pengembangan Sistem Informasi Akademik dalam bentuk Master Plan Sistem Informasi Akademik pada jangka pendek, menengah dan jangka panjang. Perencanaan Strategis untuk mengetahui proses bisnis yang terjadi digambarkan dalam bentuk analisis factor internal dan factor eksternal. Analisa dan Perancangan Sistem Informasi Akademik Berbasis SMS Gateway [6], yang menyimpulkan bahwa sistem akademik berbasis SMS ini membantu mahasiswa mendapatkan informasi dengan cepat.

Dengan adanya penelitian-penelitian tersebut, peneliti akan melakukan penelitian aplikasi portal akademik berbasis mobile untuk program studi D3 Manajemen Informatika FMIPA Universitas Riau. Adapun tujuan dari penelitian ini adalah membuat aplikasi portal akademik mobile berbasis Android yang akan digunakan sebagai alternatif pengaksesan informasi akademik, khususnya untuk mahasiswa D3 Manajemen Informatika FMIPA Universitas Riau. 


\section{Metode Penelitian}

A. Teknik Pengumpulan Data

1. Observasi

Proses pengumpulan data diperoleh dengan cara melakukan pengamatan secara langsung pada program studi D3 Manajemen Informatika FMIPA Universitas Riau, untuk mengetahui bagaimana cara kerja sistem yang sedang berjalan, sehingga didapatkan berbagai informasi untuk pembuatan aplikasi portal akademik.

2. Studi Pustaka

Proses ini dilakukan dengan cara mempelajari dari buku-buku dan jurnal-jurnal, untuk memperoleh acuan yang dapat digunakan untuk membahas tentang sistem informasi akademik.

\section{B. Model Pengembangan Sistem}

1. Analisa Kebutuhan Sistem

Program aplikasi portal akademik yang dibutuhkan adalah program aplikasi yang akan digunakan sebagai alternatif pengaksesan informasi akademik, khususnya untuk mahasiswa D3 Manajemen Informatika FMIPA Universitas Riau.

2. Desain Sistem

Adapun langkah-langkah yang dilakukan dalam merancang program aplikasi ini menggunakan beberapa diagram yang dibutuhkan yang ada dalam UML, antara lain, yaitu Pembuatan Use Case Diagram, Activity Diagram, Class Diagram, dan Sequence Diagram.

3. Pembuatan Program

Pembuatan program dilakukan dengan menggunakan pemograman Java, serta database menggunakan MySQL

4. Testing

Pada tahap ini dilakukan pengujian program dengan tujuan untuk mengetahui untuk mengetahui kelayakan program apakah program yang dibuat sudah sesuai dengan prosedur.

\section{Hasil dan Pembahasan}

\subsection{Analisa Aplikasi}

Analisa aplikasi merupakan penguraian dari suatu rancangan aplikasi yang utuh kedalam bagian-bagian komponennya, dengan maksud untuk mengidentifikasi permasalahanpermasalahan yang sering terjadi sehingga dapat dilihat kekurangan dan kelebihannya. Aplikasi portal akademik fokus utama dalam analisa ini.

Aplikasi portal akademik dirancang menggunakan bahasa pemrograman Java. Untuk desain tampilan dan aplikasi dipergunakan Eclipse Juno. UML berfungsi untuk mendesain rancangan aplikasi yang akan dibuat. Sedangkan $M y S q l$ digunakan dalam pembuatan database.

Data yang diinputkan dalam aplikasi portal akademik adalah data mahasiswa, data matakuliah digunakan untuk pengisia KRS, serta data nilai. Data-data yang telah didapatkan kemudian diproses, dan hasil proses pengisian KRS akan tersimpan pada database. Selanjutnya dapat ditampilkan dalam bentuk notifikasi sebagai output.

\subsection{Desain Aplikasi}

\subsubsection{Use Case Diagram}

Gambaran use case diagram adalah mahasiswa dapat melakukan isi kartu rencana studi, melihat biodata, melihat kartu hasil studi. Mahasiswa harus login terlebih dahulu sebelum melakukan kegiatan-kegiatan tersebut, dapat dilihat pada Gambar 1. 


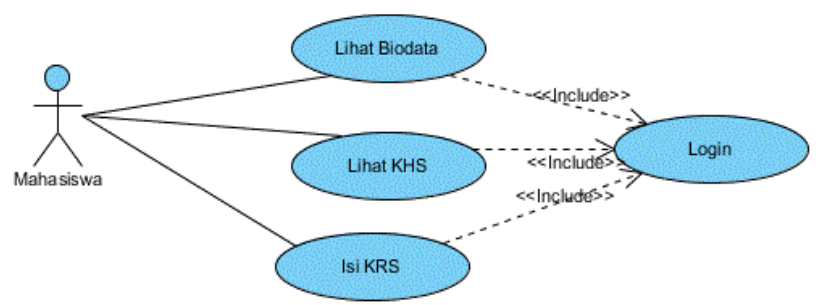

Gambar 1. Use Case Diagram Login

\subsubsection{Activity Diagram}

Activity Diagram adalah diagram yang menggambarkan aliran fungsionalitas dari sistem, yang dapat digunakan untuk menunjukkan aliran kerja bisnis (business work flow) dan dapat juga digunakan untuk menggambarkan aliran kejadian (flow of event), dapat dilihat pada Gambar 2.

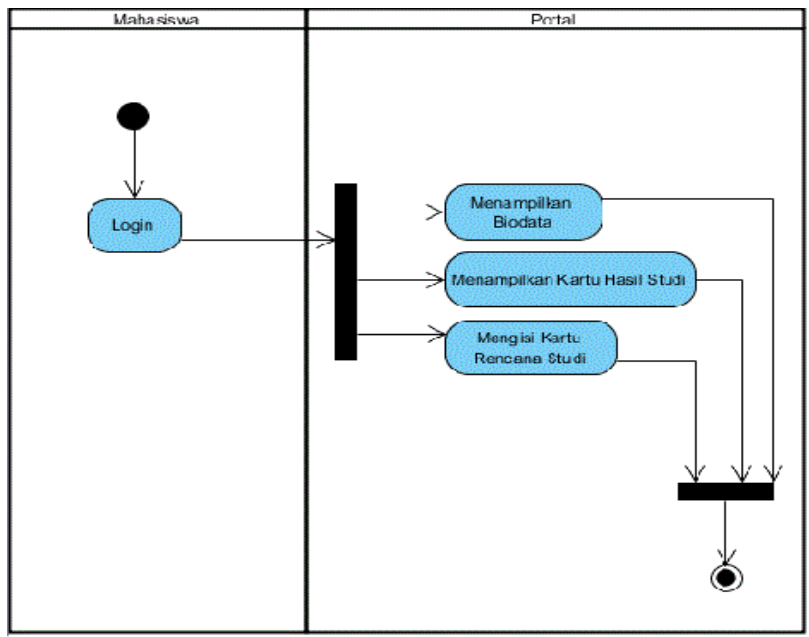

Gambar 2. Activity Diagram Aplikasi

\subsubsection{Class Diagram}

Class diagram menunjukkan interaksi antar kelas dalam system, yang merepresentasikan sesuatu yang ditangani oleh system, dapat dilihat pada Gambar 3. 


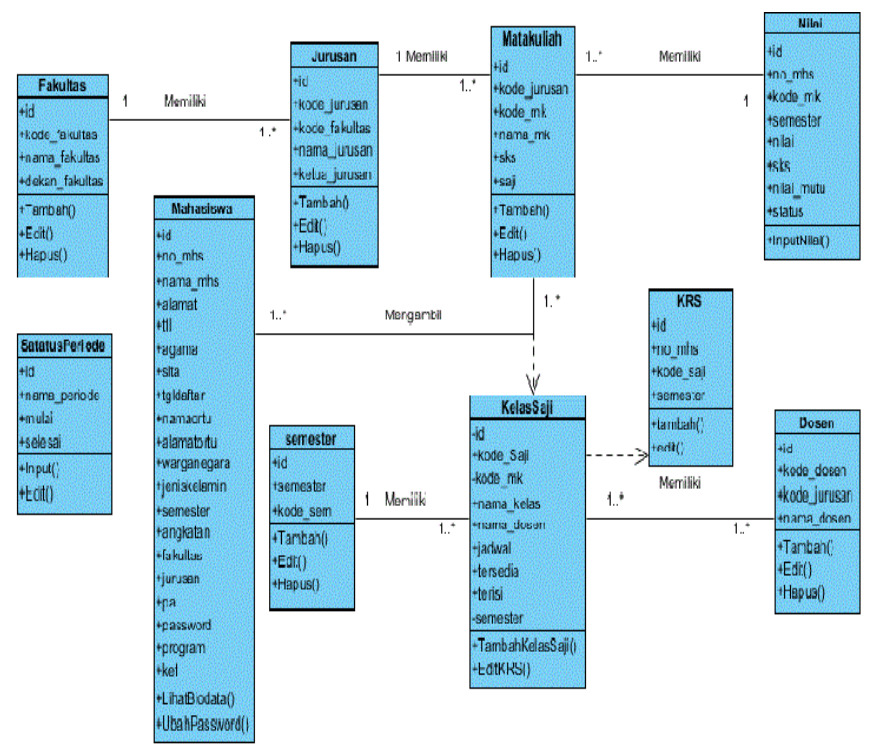

Gambar 3. Class Diagram Aplikasi

\subsubsection{Sequence Diagram}

Sequence diagram digunakan untuk menunjukkan aliran fungsionalitas dalam use case, yang merupakan diagram interaksi yang menekankan pada pengiriman pesan dalam suatu waktu tertentu secara berurutan. Beberapa tampilan sequence diagram dapat dilihat pada gambar berikut ini:

1. Sequence Diagram Login Mahasiswa

Sequence diagram untuk login Mahasiswa dapat dilihat pada Gambar 4.

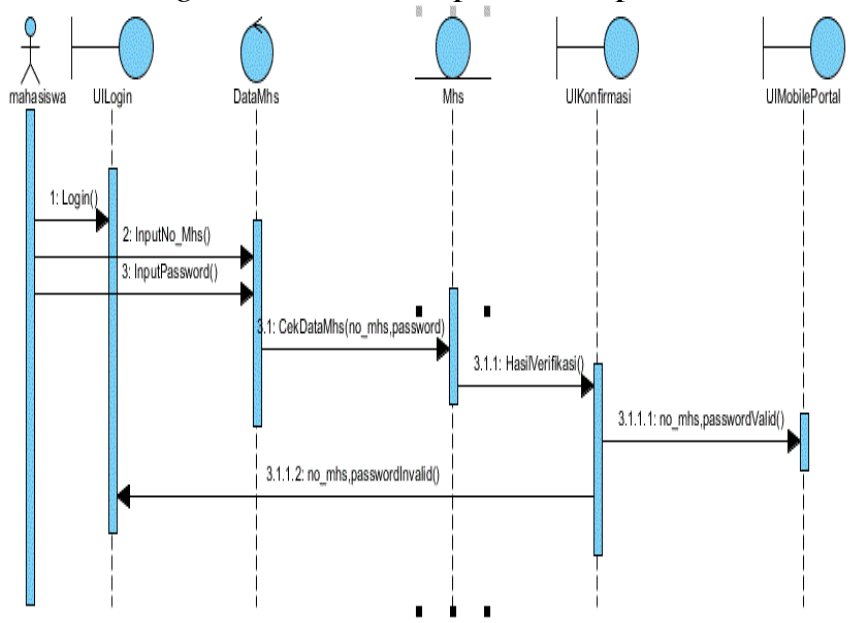

Gambar 4. Sequence Diagram Login Mahasiswa

Mahasiswa membuka Aplikasi Portal Akademik, lalu akan tampil form login. Mahasiswa memasukkan username dan password, setelah itu sistem akan mengecek dalam database mahasiswa apakah username dan password ada. Apabila username dan password tidak ada, maka sistem akan menampilkan form konfirmasi yang menyatakan username dan password tidak cocok, sehingga user diharuskan memasukkan data kembali dengan benar. Apabila username dan password ada di dalam database, maka sistem akan menampilkan tampilan halaman Mobile Portal aplikasi portal akademik. 
2. Sequence Diagram Isi KRS

Sequence diagram untuk proses pengisian Kartu Rencana Studi dapat dilihat pada Gambar 5.



Gambar 5. Sequence Diagram Isi KRS

Mahasiswa membuka menu Isi Kartu Rencana Studi, lalu mahasiswa Entri KRS,mahasiswa memilih Next maka akan muncul konfirmasi KRS yang telah di isi, mahasiswa memilih Isi KRS untuk menyimpan ke database, akan muncul konfirmasi apakah ingin melanjutkan, terakhir akan muncul pesan konfirmasi berhasil Isi KRS.

3. Sequence Diagram KHS

Sequence diagram untuk menampilkan Kartu Hasil Studi dapat dilihat pada Gambar 6.

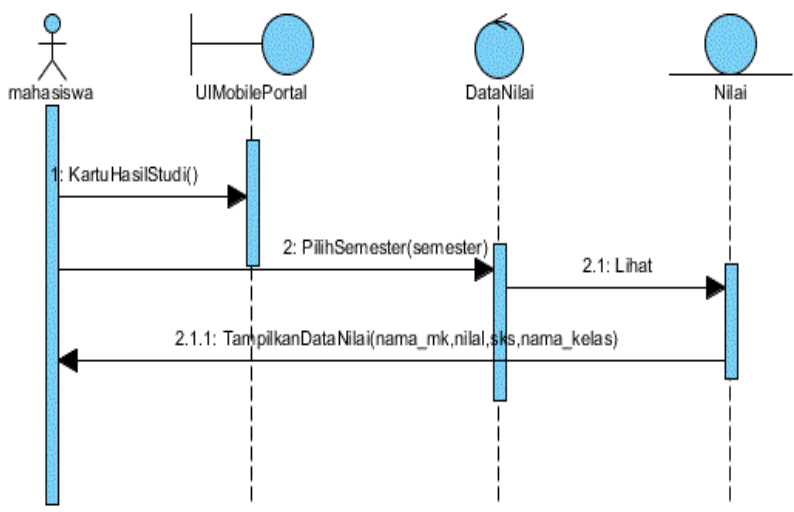

Gambar 6. Sequence Diagram KHS

Mahasiswa membuka menu KHS, lalu mahasiswa memilih semester yang akan dilihat, pilih menu Lihat maka akan tampil form KHS pada semester yang diinginkan.

4. Sequence Diagram Biodata

Sequence diagram untuk menampilkan Biodata mahasiswa dapat dilihat pada Gambar 7. 


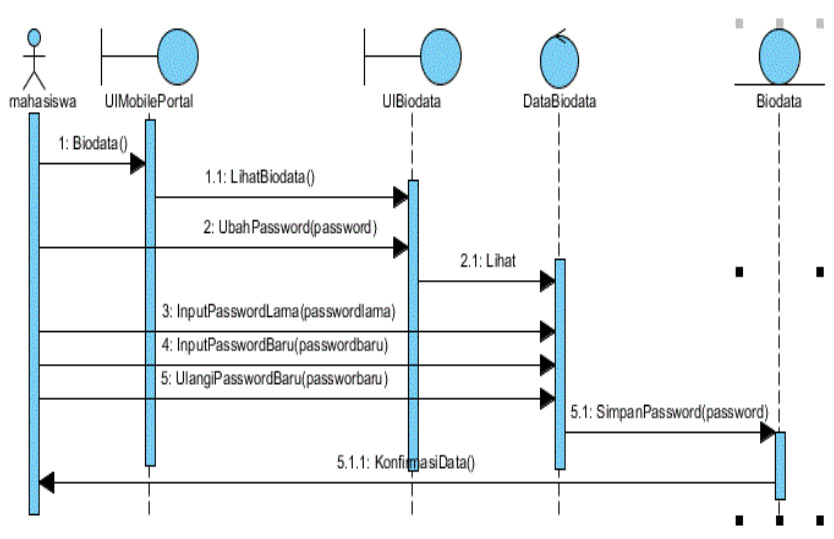

Gambar 7. Sequence Diagram Biodata

Mahasiswa memilih menu Biodata, lalu akan muncul form Biodata dimana isi dari form ini adalah data dari mahasiswa. Kemudian mahasiswa dapat melakukan perubahan password yang lama menjadi password yang di inginkan, dengan cara pilih ubah password. Lalu akan muncul form Edit Profile, lalu masukkan password lama, password baru, ulangi password baru, kemudian pilih tombol Ok maka akan muncul pesan konfirmasi bahwa perubahan password berhasil.

\subsection{Rancangan Database}

Rancangan Database dapat dilihat pada Gambar 8.

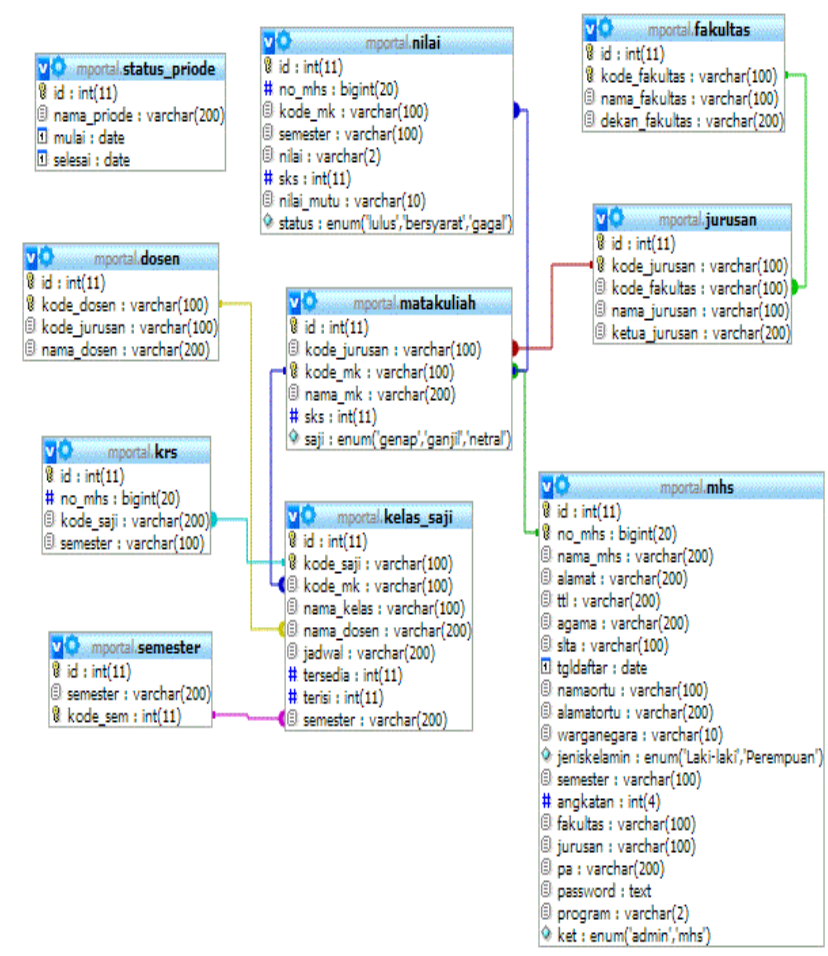

Gambar 8. Rancangan Basis Data 


\subsection{Implementasi}

Implementasi yaitu tahap untuk menerapkan semua desain kedalam pembuatan program yang menggunakan bahasa pemograman Java dengan menggunakan Eclipse. Untuk menjalankan aplikasi digunakan emulator yang telah tersedia di Eclipse dan juga mnggunakan handphone Android.

\subsubsection{Pembuatan Program}

Berikut ini merupakan salah satu print screen source code proses pembuatan aplikasi, dapat dilihat pada Gambar 9.

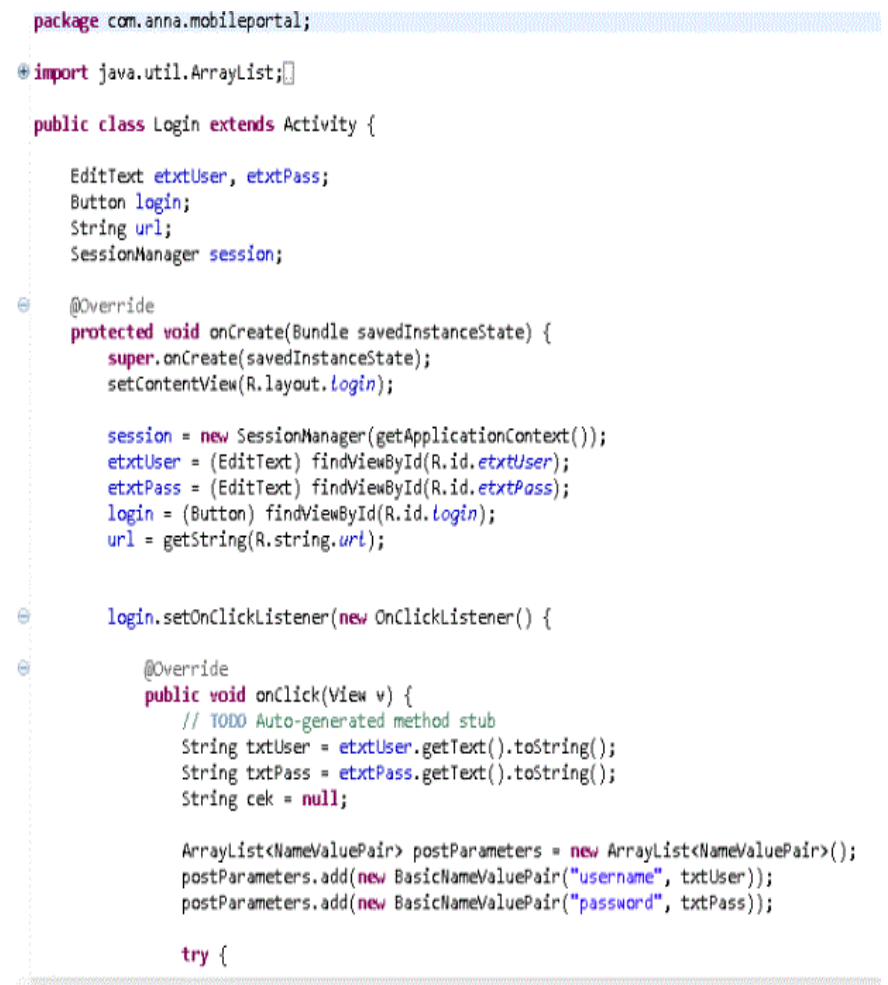

Gambar 9. Source Code Login Aplikasi

\subsubsection{Tampilan Hasil}

Hasil dari program aplikasi portal akademik adalah sebagai berikut :

1. Tampilan Splashscreen Aplikasi, ketika aplikasi dijalankan pada emulator, maka akan menampilkan splashscreen pada emulator. Yang Dapat dilihat pada Gambar 10.

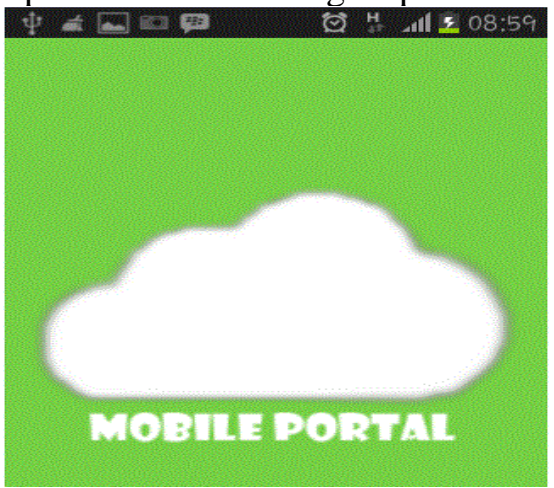

Gambar 10. Tampilan Splasscreen 
2. Tampilan Loginscreen Aplikasi, setelah tampilan spashscreen selanjutnya yaitu tampilan login screen, tampilan login screen pada emulator dapat dilihat pada Gambar 11.

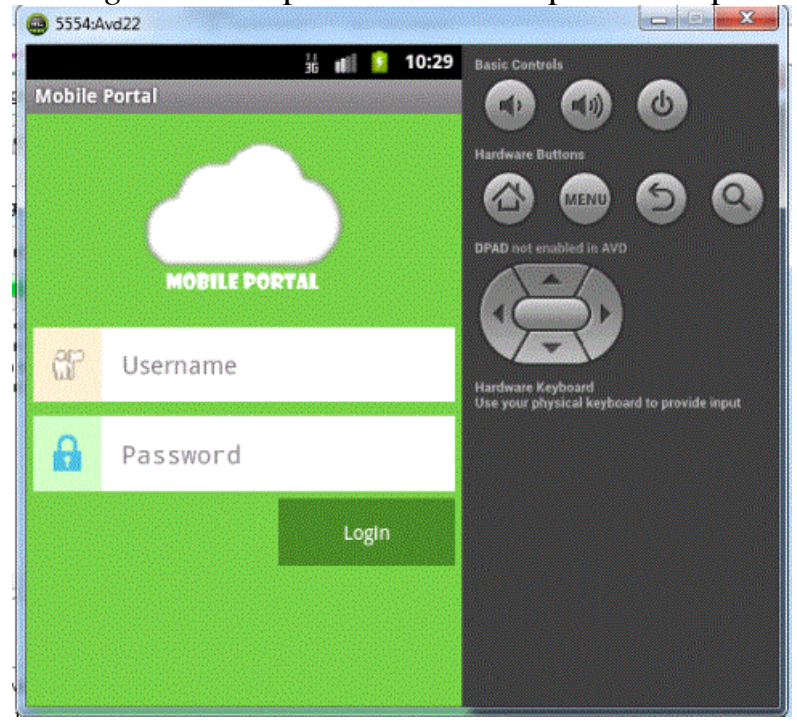

Gambar 11. Tampilan Loginscreen

Tampilan diatas merupakan langkah pertama untuk masuk ke menu utama. Untuk masuk ke menu utama, mahasiswa harus memasukkan username dan password dengan benar.

3. Tampilan Menu Utama. Setelah user atau mahasiswa melakukan login dengan Nim dan Password masing-masing, maka selanjutnya akan tampil menu utama dari aplikasi. Menu utama tersebut terdiri dari, Biodata yaitu data mahasiswa yang sedang login di aplikasi, Kartu Hasil Studi merupakan informasi tntang hasil studi mahasiswa pada semester yang bersangkutan, Isi Kartu Rencana Studi (KRS) adalah kartu yang berisi daftar mata kuiah yang akan diikuti oleh setiap mahasiswa dalam satu semster. menu utama pada aplikasi dapat dilihat pada Gambar 12.

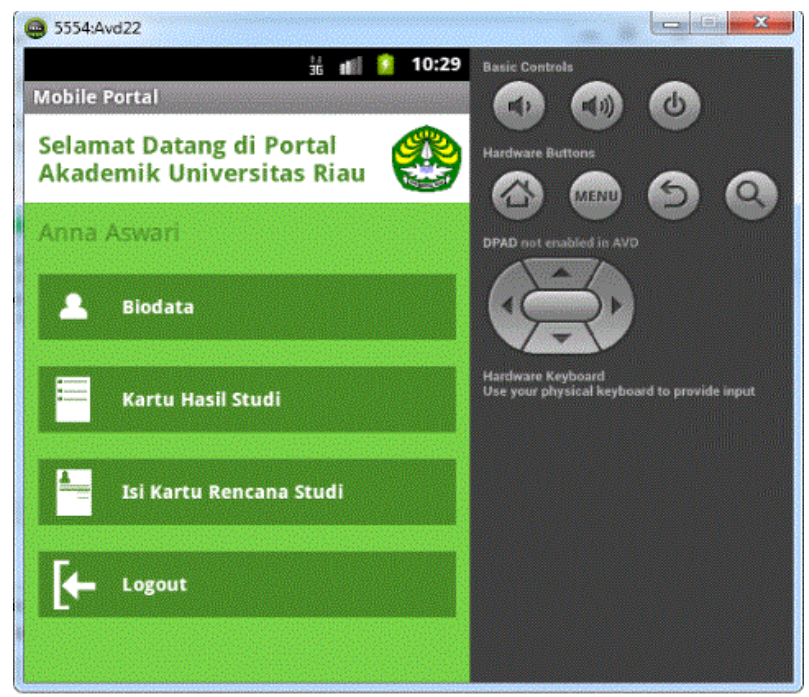

Gambar 12. Tampilan Menu Utama Aplikasi 
4. Tampilan Menu Biodata. Berikut ini adalah Tampilan profil pengguna aplikasi ketika user (mahasiswa) memilih menu Biodata. Tampilan menu biodata dapat dilihat pada Gambar 13.

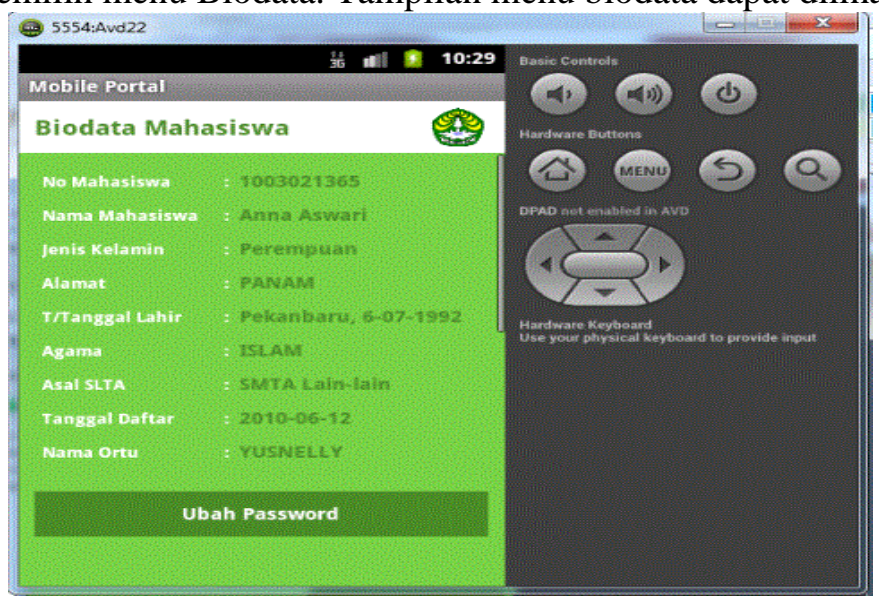

Gambar 13. Tampilan Biodata Mahasiswa

Pada menu biodata ini mahasiswa dapat melakukan perubahan password default menjadi password yang diinginkan. Berikut adalah tampilan ubah password pada Gambar 14. dan tampilan konfirmasi ubah password pada Gambar 15.

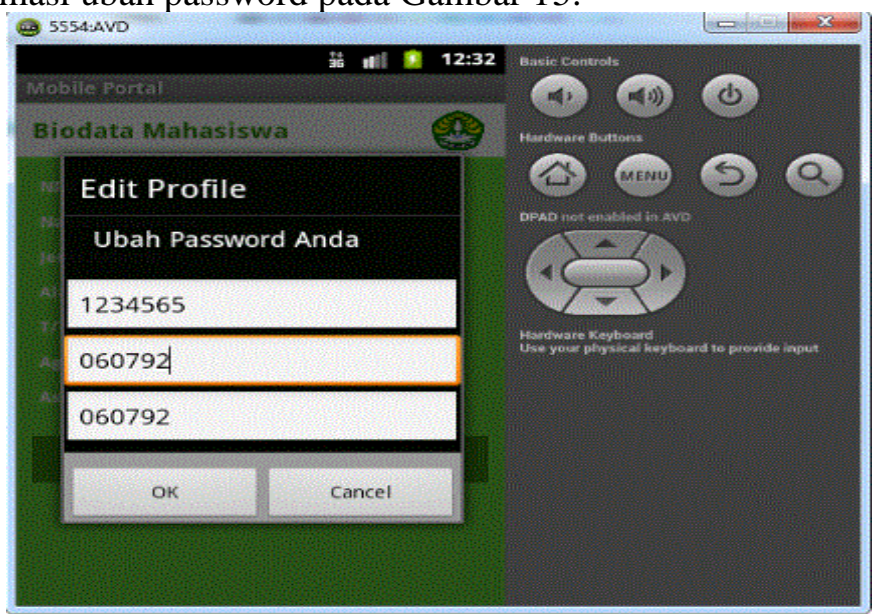

Gambar 14. Tampilan Ubah Password



Gambar 15. Tampilan Konfirmasi Ganti Pasword 
5. Tampilan Kartu Rencana Studi. Berikut ini beberapa tampilan dari proses pengisian KRS dapat dilihat pada Tampilan isi KRS dapat dilihat pada Gambar 16., selanjutnya tampilan Konfirmasi isi KRS dapat dilihat pada Gambar 17., dan Tampilan proses penyimpanan KRS Gambar 18.

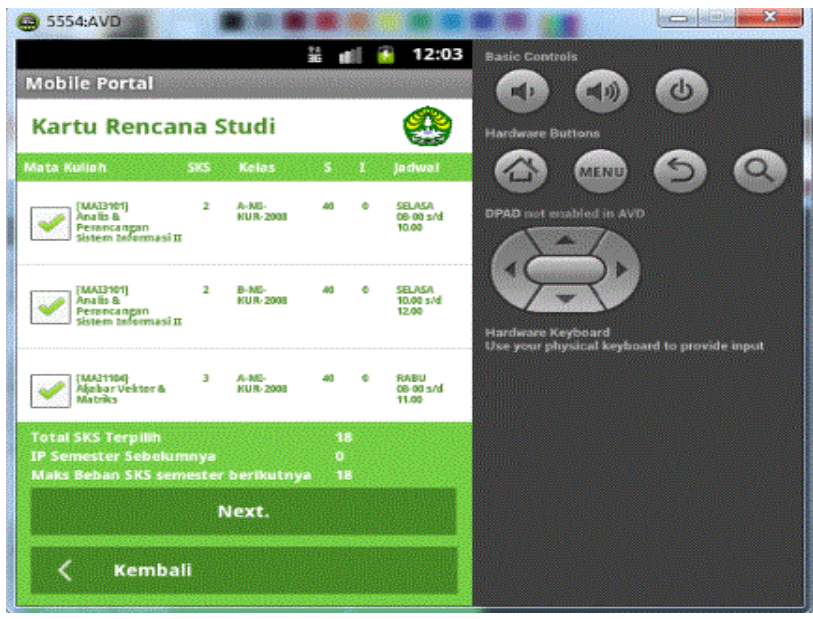

Gambar 16. Tampilan Isi KRS



Gambar 17. Tampilan Konfirmasi Isi KRS

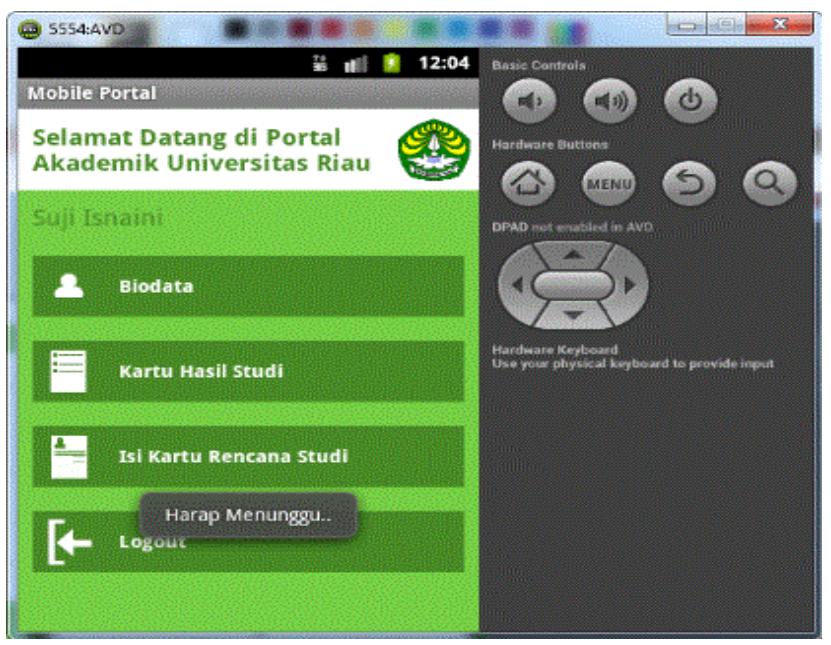

Gambar 18. Tampilan Proses Penyimpanan KRS 
6. Tampilan Menu Kartu Hasil Studi. Berikut ini adalah tampilan Kartu Hasil Studi mahasiswa yang sedang menggunakan aplikasi dapat dilihat pada Gambar 19.



Gambar 19. Tampilan KHS

\section{Kesimpulan}

Dengan adanya aplikasi portal akademik ini, maka :

a. Mempermudah mahasiswa dalam mengakses portal akademik tidak hanya berbasis web namun juga berbasis mobile

b. Aplikasi portal akademik ini dapat berjalan di emulator dan juga dapat berjalan di perangkat mobile yang memiliki sistem operasi berbasis Android dengan minimal versi 2.3.3 (Ginger Bread).

c. Aplikasi portal akademik pada handphone menggunakan username dan password sesuai dengan nomor induk masing-masing mahasiswa.

\section{Daftar Pustaka}

[1] Susanti, D.W. dan Somantri, O. Aplikasi KRS Online Berbasis Web dan Mobile pada Program Studi DIII Teknik Komputer Politeknik Harapan Bersama Tegal. Jurnal Informatika: Jurnal Pengembangan IT. 2016; 1(1): 14-17.

[2] Susanti, M. Perancangan Sistem Informasi Akademik Berbasis Web pada SMK Pasa Minggu Jakarta. Jurnal Informatika. 2016: 3(1): 91-99.

[3] Wiguna, W. Adopsi Sistem Informasi Akademik Perguruan Tinggi BSI Bandung Berbasis TAM. Jurnal Informatika. 2017; 4(2): 189-197

[4] Damani, I. S. Portal Akademik Semi-Realtime AMIK dan STIKOM Tunas Bangsa Pematangsiantar. Informatika dan Teknologi Jaringan (Infotekjar). 2016; 1(1): 70-74

[5] Mumtahana, H.A., Winarno, W. W. dan Sunyoto, A. Perancangan Master Plan Sistem Informasi Akademik STT Dharma Iswara Madiun. Jurnal Ilmu Komputer dan Informatika. 2016: 2(2). 
[6] Hidayatuloh, S. dan Suseno, H.B. Analisa dan Perancangan Sistem Informasi Akademik Berbasis SMS Gateway dalam melihat Nilai Akhir Mata Kuliah "Studi Kasus : Mata Kuliah Algoritma Pemrograman dan Struktur Data". Jurnal Sistem Informasi. 2013. 6(1)

[7] Supriyono, H., Nur Saputra, A., Sudarmilah, E. dan Darsono, R. Rancang Bangun Aplikasi Pembelajaran Hadis untuk Perangkat Mobile Berbasis Android. Jurnal Informatika. 2014. 8(2).

[8] Safaath H, Nazaruddin. Pemograman Aplikasi Mobile Smartphone dan Tablet PC Berbasis Android. Bandung:Informatika. 2012

[9] Anggraini, Purwita. 2012. Aplikasi Mobile Pemandu Pariwisata Kota Bandung Berbasis J2me ( Java 2 Micro Edition ). Skripsi Program Studi Sistem Informasi Fakultas Teknik dan Ilmu Komputer, Universitas Komputer Bandung. 2012.

[10] Adhari, Ismail. Perancangan Aplikasi Berat Badan Ideal Berbasis Android. Skripsi Program Studi Sistem Informasi Fakultas Teknik dan Ilmu Komputer, Universitas Komputer Bandung. 2012 